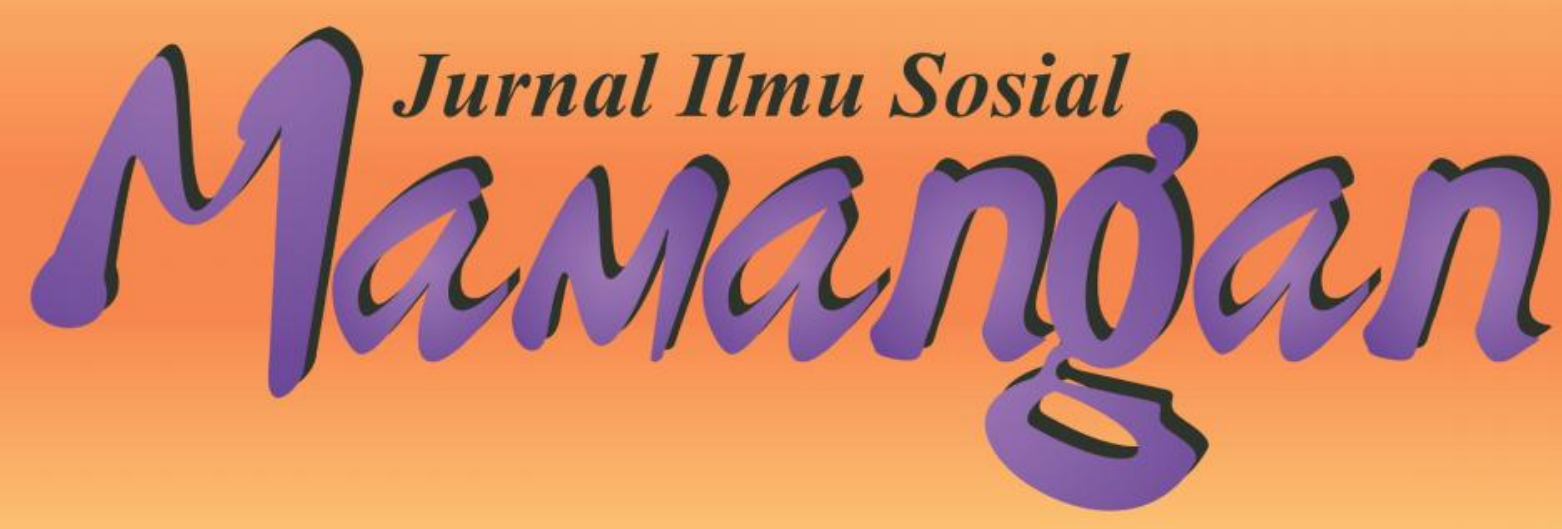

Kehidupan Sosial Ekonomi Petani Nilam Di Desa Taikako, Kec. Sikakap, Kab. Kepulauan Mentawai

YantiMurni, Ansofino \& Meldawati

Dampak Sosial Konflik Kinali 1999-2010

Welly lbrahim, Ansofino \& Ahmad Nurul Huda

Pasang Surut Sosial Ekonomi Petani Cengkeh Di Nagari Koto Anau, Kec. Lembang Jaya, Kab. Solok 1960-2011

Yosefrizal, Sabar \& Witrianto

Perubahan Sosial Ekonomi Masyarakat Pasca Pengembangan Wisata Bahari Di Kepulauan Sikakap, Kabupaten Mentawai

Ismi Andriyani, Etmi Hardi \& Liza Husnita

Persepsi Masyarakat Petani Kelapa Terhadap Pendidikan Tinggi Anak Di Kecamatan Siberut Barat, Kabupaten Kepulauan Mentawai

A. Tisnawati Tapondhadhai, Ansofino \& Ranti Nazmi

Kecendrungan Masyarakat Membeli Lahan Sengketa Di Kecamatan VII Koto, Kabupaten Tebo, Jambi

Esri Eni Dewi Mukti, Slamet Rianto \& Dasrizal 


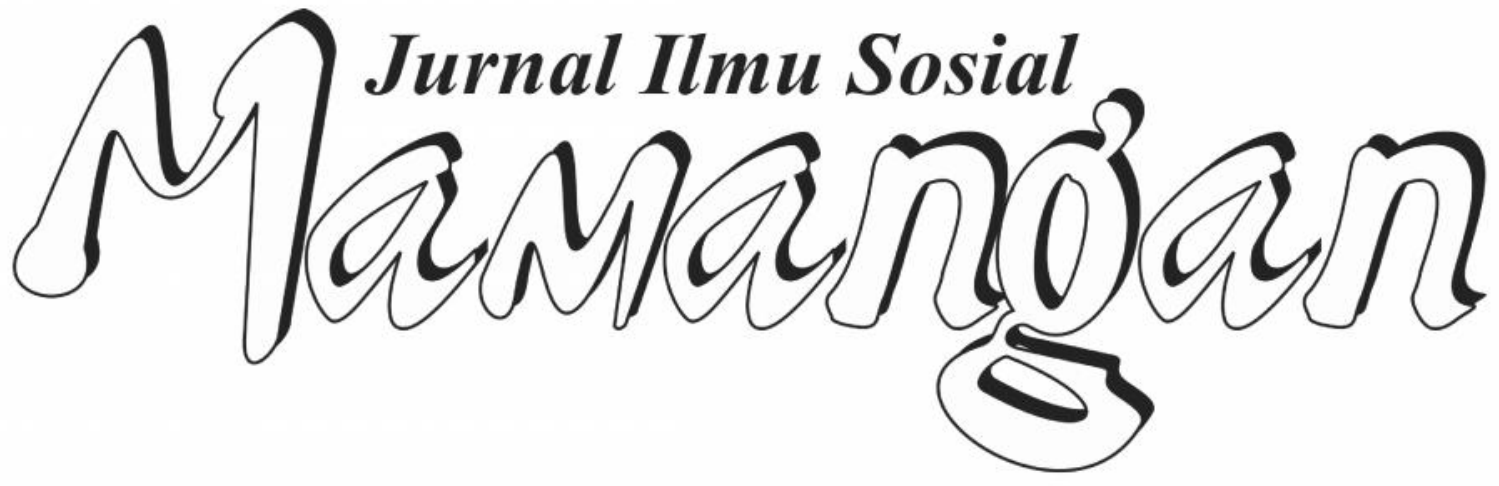




\section{Mitra Bestari}

Prof. Dr. Afrizal, MA. (FISIP, Unand Padang)

Dr. A. Latief Wiyata, M. Si. (Universitas Jember, Jember)

Prof. Dr. Badaruddin, M. Si. (FISIP, USU Medan)

Dr. Fikarwin Zuska, M. Si. (FISIP, USU Medan)

Nurus Shalihin, M. Si., Ph.D. (Fak. Ushuluddin IAIN Imam Bonjol Padang)

Dr. Semiarto A. Purwanto, M. Si. (FISIP, UI Jakarta)

Dr. Wahyu Wibowo, M. Si. (Universitas Nasional, Jakarta)

\section{Dewan Redaksi}

Dr. Zusmelia, M. Si.

Dr. Maihasni, M. Si.

Adiyalmon, S. Ag., M. Pd.

Firdaus, S. Sos., M. Si.

\section{Pemimpin Redaksi}

Firdaus, S. Sos., M. Si.

\section{Anggota Redaksi}

Dian Kurnia Anggreta, S. Sos., M. Si.

Rinel Fitlayeni, S. Sos., MA.

Surya Prahara, SH.

ISSN: 2301-8496

\section{Alamat Redaksi:}

Laboratorium Program Studi Pendidikan Sosiologi, STKIP PGRI Padang

Jl. Gunung Pangilun, Padang

Email: redaksimamangan@yahoo.com

Penerbit :

Program Studi Pendidikan Sosiologi, STKIP PGRI Padang

\section{Contac person :}

Firdaus (Hp. 085263881221/Email : daus gila@yahoo.com) 


\section{DAFTAR ISI}

Kehidupan Sosial Ekonomi Petani Nilam Di Desa Taikako, Kec. Sikakap, Kab. Kepulauan Mentawai

Yanti Murni, Ansofino \& Meldawati.

$60-72$

Dampak Sosial Konflik Kinali 1999-2010

Welly Ibrahim, Ansofino \& Ahmad Nurul Huda

Pasang Surut Sosial Ekonomi Petani Cengkeh Di Nagari Koto Anau, kec. Lembang Jaya, Kab. Solok 1960-2011

Yosefrizal, Sabar, Witrianto

Perubahan Sosial Ekonomi Masyarakat Pasca Pengembangan Wisata Bahari Di Kepulauan Sikakap, Kabupaten Mentawai

Persepsi Masyarakat Petani Kelapa Terhadap Pendidikan Tinggi Anak Di Kecamatan Siberut Barat, Kabupaten Kepulauan Mentawai

A. Tisnawati Tapondhadhai, Ansofino \& Ranti Nazmi.

Kecendrungan Masyarakat Membeli Lahan Sengketa Di Kecamatan VII Koto, Kabupaten Tebo, Jambi

Esri Eni Dewi Mukti, Slamet Rianto \& Dasrizal. 


\title{
PASANG SURUT SOSIAL EKONOMI PETANI CENGKEH DI NAGARI KOTO ANAU, KEC. LEMBANG JAYA, KAB. SOLOK 1960-2011
}

\author{
Yosefrizal, Sabar, Witrianto \\ Sekolah Tinggi Keguruan dan Ilmu Pendidikan (STKIP) PGRI Sumatera Barat
}

\begin{abstract}
This research aim to the dynamic of socio-economic of farmers clove in nagari Koto Anau during 1960-2011. The purpose is to describe farmers clove life before and after 1960, marketing strategy of clove, and effect of clove to farmers socio-economic 1960-2011. Research conducted with four steps, heuristic, critical resources, interpretation and histografy. Data collected by interview with clove farmers. Secondary sources that support this study were obtained from library research.
\end{abstract}

Keywords : Socio-Economic, Farmer Clove, Koto Anau

\begin{abstract}
ABSTRAK
Penelitian ini mengkaji tentang dinamika yang terjadi dalam kehidupan sosial ekonomi petani cengkeh di nagari Koto Anau pada tahun 1960-2011. Tujuan penelitian ini untuk menjelaskan tentang kehidupan petani cengkeh Koto Anau sebelum tahun 1960 dan sesudah tahun 1960, strategi pemasaran cengkeh di koto anau, pengaruh tanaman cengkeh terhadap kehidupan sosial ekonomi petani Koto Anau tahun 1960-2011. Penelitian dilakukan dengan empat tahap, yaitu heuristic, kritik sumber, interpretasi dan histografi. Pengumpulan data dilakukan melalui wawancara dengan beberapa informan, yaitu petani cengkeh di nagari Koto Anau. Sumber sekunder yang menunjang penelitian ini diperoleh dari riset pustaka.
\end{abstract}

Keywords : Sosial Ekonomi, Petani Cengkeh, Koto Anau

\section{PENDAHULUAN}

Cengkeh (syzygium aromaticum) dalam bahasa Inggris disebut cloves adalah tangkai bunga kering beraroma dari kelurga pohon myrtaceae. Cengkeh adalah tanaman asli indonesia dan banyak digunakan sebagai bumbu masakan pedas di negara-negara eropa, dan sebagai bahan utama rokok kretek khas Indonesia. Cengkeh ditanam terutama di Indonesia (kepulauan Banda) dan Madagaskar. Selain itu juga dibudidayakan di Zanzibar, India dan
Srilangka. Tanaman cengkeh merupakan tanaman tahunan yang dapat tumbuh dengan tinggi 10-20 m, mempunyai daun berbentuk lonjong yang berbunga pada pucuk-pucuknya. Tangkai buah pada awalnya berwarna hijau dan berwarna merah jika bunga sudah mekar. Cengkeh akan dipanen jika sudah mencapai panjang $1,5-2 \mathrm{~cm}$.

Cengkeh merupakan salah satu tanaman yang dibutuhkan oleh orang-orang Eropa dan mempunyai harga yang tinggi. 
Oleh karna itu cengkeh sangat baik ditanam oleh petani sebagai tanaman pokok atau sampingan. Harganya yang tinggi akan meningkatkan pendapatan petani. Pada awalnya cengkeh merupakan komoditas ekspor, akan tetapi, komoditas ini berubah menjadi komoditas impor karena pesatnya perkembangan industri rokok kretek di Indonesia berkembang sejak akhir abad ke 19. Tingginya kebutuhan akan cengkeh megakibatkan pemerintah melaksanakan program swasembada cengkeh pada tahun 1970, antara lain melalui perluasan areal (Sudarmo, 2005). Tanaman cengkeh mulai dikenal dan ditanam pada daerah-daerah bagian timur indonesia seperti Ambon, Seram, Tidore (Sartono, 1988). Setelah tahun 1839 secara keseluruhan cengkeh baru ditanam di kepulauan Indonesia. Untuk Sumatera Barat cengkeh mulai ditanam tahun 1883 (Alaudin, 1977).

Salah satu daerah yang memproduksi cengkeh di Sumatera Barat adalah nagari Koto Anau yang terletak di Kabupaten Solok. Pada tahun 1950, ketika cengkeh mendapat pasaran yang baik dalam sektor perdagangan, maka masyarakat Koto Anau berusaha untuk menanam dan memperluas ladang-ladang cengkeh mereka. Ini terbukti bahwa hampir setiap lahan pertanian mereka yang sekiranya memungkinkan, ditanami dengan cengkeh. Hutan-hutan yang agak jauh dari pemukiman penduduk menjadi sasaran petani untuk dibuka dan dijadikan ladang-ladang cengkeh (Irdawati, 1997)

Selama periode 1950-1965 Koto Anau merupakan salah satu daerah pengasil cengkeh di Sumatera Barat. Koto Anau mengalami masa gemilang sebagai penghasil cengkeh pada tahun 1960. Pada tahun ini Koto Anau menjadi penghasil cengkeh terbesar di Sumatera Barat dimana sebagian besar setiap rumah atau kepala keluarga di memiliki batang cengkeh. Secara tidak langsung hal ini membuat ekonomi masyarakat Koto Anau meningkat drastis dan mulailah bermunculan orang kaya baru di Koto Anau. Penghasilan cengkeh telah menyebabkan nagari ini pernah menjadi nagari yang kaya di Sumatera Barat, ketika harga cengkeh berkisar Rp $1.500 / \mathrm{kg}$ di tahun 1960-an. Harga ini setara dengan 3,5 gram emas 24 karat. Jika dibandingkan dengan harga beras sama dengan $50 \mathrm{~kg}$ beras. Karena harga cengkeh yang tinggi, maka banyak orang-orang dari luar Koto Anau seperti Maninjau, Alahan Panjang, Payakumbuh, Bengkulu, Kerinci dan aerah lainya datang ke Koto Anau untuk bekerja dengan pemilik lahan cengkeh sebagai buruh tani (Irdawati, 1997). Peningkatan ekonomi masyarakat Koto Anau ini juga dapat dibuktikan dengan sudah adanya listrik di Koto Anau pada tahun 1952 yang digerakan oleh diesel yang dibeli dengan swadaya masyarkat. (Zubir, 1987).

Pada akhir tahun 1965 pohon cengkeh di ladang-ladang petani Koto Anau terserang penyakit yang mengakibatkan pohon cengkeh mengalami kematian. Kematian terjadi pada semua pohon baik yang masih muda maupun yang telah tua. Keadaan ini berpengaruh terhadap kehidupan petani karena mereka kehilangan sumber mata pencarianya. Kematian Cengkeh terus bertambah pada tahun 1967-1969, sebagian besar pohonpohon cengkeh di Koto Anau tidak lagi menghasilkan pada tahun 1970 (Djafaruddin, 1970). Tahun 1980 an harga cengkeh turun drastis dan para petani tidak mampu menikmati hasil cengkehnya. Namun harga cengkeh tersebut kembali naik pada tahun 1990. Pada tahun 1990 sampai tahun 2011 kehidupan masyarakat Koto Anau mulai kembali normal karena hasil tanaman cengkeh telah mampu menjadi tumpuan ekonomi masyarakat.

Pasang surut kehidupan petani cengkeh terjadi dalam struktur sosial ekonomi, yang merupakan pengaruh dari hasil budidaya cengkeh. Arikel ini akan membahasa tentang kehidupan petani cengkeh di Koto Anau sebelum tahun 1960 dan pengaruh tanaman cengkeh terhadap kehidupan sosial ekonomi petani Koto Anau tahun 1960 -2011. Penulisan ini dibatasi secara spasial di nagari Koto Anau Kecamatan Lembang jaya, Kabupaten Solok karena nagari ini sukses dalam rentang waktu 1950-1965 sebagai penghasil cengkeh terbesar di sumatera barat. Secara temporal, penulisan dibatasi pada 1960 yang merupakan masa-masa para petani sejahtera dengan hasil cengkeh hingga tahun 2011 yang merupakan masa dimana para petani berupaya menanam kembali dan dapat menikmati hasil cengkeh setelah mengalami pasang surut. 


\section{PASANG SURUT CENGKEH DI NAGARI KOTO ANAU}

Tanaman cengkeh bukanlah tanaman yang asing bagi masyarakat Koto Anau. Mereka telah mengenal cengkeh dari tahun 1860-an, yaitu pada masa penjajahan pemerintah Belanda. Menurut cerita yang berkembang pada saat itu Laras Koto Anau mendapatkan bibit cengkeh dari Van Rayen seorang asisten Residen. Kemudian Laras ini membagikan bibit cengkeh tersebut kepada sebagian masyarakat Koto Anau dan menananmnya di ladang-ladang serta pematang sawah. Semenjak itu, tanaman cengkeh menjadi tanaman sampingan bagi masyarakat Koto Anau selain kelapa, kopi, dan buah-buahan. Namun keadaan ini berubah pada tahun 1927, pada saat harga cengkeh naik menjadi $\mathrm{Rp}$ 50-80/pikul (sepikul sama dengan $100 \mathrm{~kg}$ ). harga tersebut lebih tinggi dari harga hasil bumi lainya. Para petani Koto Anau lebih bersemangat menanam cengkeh karena harganya yang selalu melebihi harga tanaman lain dan menjadikan cengkeh sebagai tananman yang setara dengan menanam padi sawah.

Motivasi petani menanam cengkeh adalah karena keuntungan yang lebih besar dibandingkan dengan hasil-hasil tani yang lainya. Hal ini terlibat bahwa pohon cengkeh akan menghasilkan setelah 5 atau 6 tahun. Rata-rata pohon cengkeh akan menghasilkan 5-10 kg cengkeh kering dalam 1 tahun. Tetapi apabila pohon cengkeh telah tua maka hasilnya akan bertambah banyak. Pohon yang berumur 10-15 tahun dapat menghasilkan 10-30 kg cengkeh kering dalam setahun. Melihat keadaan seperti ini membuat petani-petani di Koto Anau semakin tertarik menanam cengkeh. Hal ini terbukti pada tahun 1936, cengkeh tidak hanya ditanam di pekarangan rumah saja, tetapi juga dipematang sawah dan ladang-ladang yang berkisar antara 30100 batang (Irdawati, 1997)

Pada tahun 1960-an merupakan masamasa yang sulit bagi petani cengkeh. Pada saat itu harga cengkeh masih tetap tinggi, tetapi banyak pohon cengkeh yang diserang penyakit dan menyebabkan pohon cengkeh mati. Akibat dari penyakit cengkeh tersebut menyebabkan motivasi petani menanam dan merawat cengkeh berkurang. Bahkan banyak diantara petani yang tidak mau mengurus cengkehnya dan memilih pergi merantau untuk mencari penghidupan yang lain. Para petani lebih suka memilih menjadi penjual daging daripada menjadi petani cengkeh. Namun tidak semua petani cengkeh yang pergi merantau dan meninggalkan kampungnya. Masih ada beberapa petani yang tetap bertahan di Koto Anau dan mengurus cengkehnya dengan berbagai kondisi yang tidak mendukung. Petani-petani yang telah memasuki usia tua, yang tidak memungkinkan untuk pergi merantau memilih untuk menetap di Koto Anau dan mengurus cengkeh dan keluarganya.

Motivasi petani untuk mengolah cengkeh tetap menurun padda dekade 1980-an. Hal ini dilatarbelakangi oleh faktor rendahnya harga cengkeh di pasaran. Sehingga banyak pohon cengkeh yang telah dirawat oleh petani diabaikan. Harga cengkeh hanya berkisar antara Rp 200$500 / \mathrm{kg}$. Harga tersebut tidak sebanding dengan harga cengkeh sebelumnya dan tidak seimbang dengan kebutuhan petani waktu itu. Akibatnya usaha mengolah cengkeh hanya dijadikan sebagai kegiatan sekunder atau kegiatan pendukung bagi petani. Mengolah cengkeh hanya dijadikan usaha sampingan, sedangkan untuk kegiatan utama petani menanami ladangnya dengan tanaman kopi, caseavera dan tanaman lainya.

Pada tahun 1995 masyarakat Koto Anau kembali mengolah cengkeh dengan serius karena bertani cengkeh sama dengan menanam modal untuk jangka yang panjang. Karena cengkeh semakin tua semakin banyak dan cengkeh akan selalu dibutuhkan oleh masyarakat dalam negeri maupun luar negeri. Disamping itu petani yang mengolah cengkeh tidak tertutup kemungkinan juga melakukan kegiatan yang dapat menghasilkan uang, seperti ke sawah atau bertani dengan tanaman uyang lain. Pada awal tahun 2000 masyarakat Koto Anau telah dapat kembali menikmati hasil cengkeh. Petani cengkeh Koto Anau telah mampu membiayai pendidikan anaknya sampai tingkat perguruan tinggi. Sampai sekarang mengolah cengkeh masih dijadikan masyarakat Koto Anau sebagai usaha utamanya. Sampai sekarang masyarakat masih tetap melestarikan 
cengkeh sebagai tanaman khas masyarakat Koto Anau sampai 2011.

Ladang cengkeh yang dimiliki oleh petani-petani cengkeh di Koto Anau berkisar 1 Ha sampai dengan $10 \mathrm{Ha}$. petanipetani yang memiliki ladang seluas $1 \mathrm{Ha}$ atau kurang adalah yang paling besar jumlahnya $(79,5 \%)$, sedangkan yang memiliki ladang lebih besar dari 1 Ha tetap lebih kecil dari $5 \mathrm{Ha}$ adalah 18,8\%. Hanya $1,7 \%$ dari mereka yang memiliki ladang cengkeh lebih dari $5 \mathrm{Ha}$, tetapi lebih kecil dari 15 Ha. Satu hektar ladang cengkeh biasanya berisi 150-600 batang. Walaupun rata-rata pohon yang dimiliki mereka sudah berumur 15-30 tahun pada tahun 1950. Keadaan ini menguntungkan petani karena potensi produksi pohon cengkeh yang berumur agak tua adalah yang paling baik.

Petani-petani cengkeh di Koto Anau dapat dikelompokan dalam kelompok yang berpendapatan tinggi ketika harga cengkeh sangat tinggi. Bagi petani yang memiliki jumlah pohon yang banyak dan umur pohonya telah tua dapat merasakan uang hasil penjualan cengkeh, sedikit sekali petani cengkeh di Koto Anau (40\%) yang mempunyai pendapatan kurang dari Rp.200.000 setiap kali panen. Mereka yang termasuk kelompok ini adalah peteni-petani pemula yang pohon cengkehnya masih sedikit produksi buahnya. Namun setelah cengkeh mereka berumur di atas 5 tahun, mereka mendapatkan penghasilan yang tinggi setiap kali panen.

Dari hasil penjualan cengkeh dapat menyebabkan para petani cengkeh mampu membeli berbagai macam perabot rumah tangga, membeli emas, pakaian, dan memperbaiki rumah atau membangun rumah. Hampir setiap rumah memiliki radio transiator,tape recorder dan piringan hitam. Sedangkan seluruh nagari diterangi dengan listrik tenaga diesel. Menurut petani, mendapatkan uang ribuan rupiah dalam seminggu adalah hal mudah, hanya dengan cara mengumpulkan cengkeh yang berjatuhan disekitar batang pohon cengkeh. Keuntungan penjualan cengkeh juga digunakan untuk memiliki sarana-sarana fisik mobil.

Dalam melakukan usaha pertanian cengkeh dibutuhkan tenaga kerja lepas, karena hanya pada masa panen saja. Tenaga kerja bukanlah masyarakat Koto Anau sendiri, melainkan didatangkan dari luar Koto Anau seperti Koto Laweh, Alahan Panjang, Talang Babungo, Bukit Sileh, Maninjau, dan lain masih banyak daerah lainya. Jumlah tenaga kerja tergantung luas areal. Dan banyaknya jumlah pohon yang dimiliki petani. Rata rata jumlah tenaga kerja yang dipakai untuk pemetikan pada musim cengkeh untuk lahan seluas 1 ha dengan jumlah pohon 200-250 batang adalah 30 orang. Pemetik daalam 1 hari kerja (lebih kurang 7 jam) dapat memetik memetik maksimal $40 \mathrm{~kg}$ cengkeh basah(lebih kursng 30 kg cengkeh kering). Sedangkan pada masa akhri musim panen rata-rata hanya $25 \mathrm{~kg}$.

Hubungan kerja antara petani pemilik dengan buruh tani tidak hanya memebntuk hubungan antara buruh dan majikan, tetapi juga berbentuk hubungan kekeluargaan. Buruh tani cengkeh di Koto Anau bukanlah buh tetap yang digaji per bulan, tetapi merupakan buruh lepas yang digaji sebatas selesai suatu kerja. Biasanya mereka menerima upah sebesar 5\% dari jumlah cengkeh yang berhasil mereka petik. Selanjutnya untuk tempat tinggal pekerja bertempat di rumah majikan. Namun ada juga beberapa pekerja yang bekerja di ladang-ladangcengkeh dengan memabangun sebuah rumah kecil (pondok). Rajo Bujang seorang buruh pekerja buruh cengkeh pada masa itu, beliau berasal dari Koto Laweh yang mana pada saat melaksanakan pekerjaanya ia tinggal di ladang. Disamping itu juga bekerjasebgai pemetik cengkeh, mereka juga bisa menanam sayur-sayuran dan buah-buahan di ladang.

Selanjutnya menurut Rajo Bujang ada beberapa pekerja cengkeh mereka lebih senang tingal di rumah majikan pada saat bekerja, karena setelah bekerja di ladang ia juga bisa bekerja di rumah untuk memisahkan cengkeh dari tangkainya, yang mana upah pemisahan tangkai cengkeh ini diluar upah pemetikan cengkeh. Berdasarkan data diatas dapat dipahami bahwa tenaga kerja yang bertugas memetik buah cengkeh umumnya berasal dari luar Koto Anau. Mereka mendapat upah dari pemilik cengkeh. Para pekerja yang berasal dari luar Koto Anau juga mendapatkan fasilitas tempat tinggal dari pemilik cengkeh. Dengan demikian keuntungan 
yang didapatkan dari hasil cengkeh tidak saja bagi pemilik cengkeh, namun juga bagi para pekerja yang datang ke Koto Anau.

\section{PEMASARAN CENGKEH NAGARI KOTO ANAU}

Pemasaran produksi merupakan elemen yang sangat penting. Kegiatan atau aspek produktif saja belum tentu mendapatkan hasil yang berbentuk uang kepada petani. Para petani harus menjual produksinya untuk mendspstksn usng. Pada kenyataan tersebut jelas bahwa pendapatan petani juga bergantungkepada pemasaran hasil. Sejak tahun 1950-an terlihat bahwa pemasaran cengkeh di Koto Anau tidak mengalami hambatan karena pasar slalu siap menampung. Para petani bebas menjual cengkehnya kepada pedagang pengumpul. Tidak ada organisasi sosial yang mengatur masalah penjualan cengkeh. dalam pemasaran hasil cegnkeh, petanipetani cengkeh di Koto Anau menjual cengkehnya langsung ke pakan (pasar) yang ada di Koto Anau pada hari Senin dan Kamis. Disamping itu terdapat juga para petani yang menjual cengkehnya langsung ke pasar Solok, dan ke ibukota Provinsi (Padang) dengan alasan cengkeh dapat dijual dengan harga yang lebih tiggi jika dibandingkan dengan harga penjualan di Koto Anau. Selain hal tersebut juga disebabkan keinginan petani untuk berbelanja sekaligus jalan-jalan.

Namun demikian tidak semua petani menjual cengkehnya ke pasar, karena para petani yang mempuyai ladang cengkeh yang agak jauh dari pemukiman penduduk menemui kesulitan dalam mengangkut hasil panen ke rumah atau menjual cengkeh langsung ke pasar. Akibatnya timbul pedagang perantara yang mendatangkan keuntungan para petani kerana mereka dapat dengan mudah menjual cengkeh di ladang mereka masing-masing. Akan tetapi disisi lain petani memperoleh harga yang lebih rendah dibandingkan dengan harga pasar. Selisih harga yang terjadi maksimum Rp. 500-1000/kg.

Pedagang perantara atau pedagang pengumpul baik besar atau kecil memegang peranan penting dalam pemasaran cegnkeh untuk melancarkan komoditi dari petani produsen kepad eksportir. Didukung oleh letak ladang cengkeh yang menyebar di
Koto Anau, maka pedagang berkumpul sebagai pedagang pengumpul. Tujuan utama jual beli mereka adalah mencari keuntungan, sehingga mereka selalu berusaha membeli semurah-murahnya dan menjual semahal-mahalnya. Pada umumya mereka menganggap usaha daganganya bersifat sementara, sehingga mereka berusaha mencari keuntugan sebesarbesarnya pada waktu panen.

Dalam pemasaran, petani cengkeh di Koto Anau juga terikat dengan sistem ijon. Sebelum panen, pedagang sudah membeli cengkeh pada saat pohon-pohon cengkeh menunjukan tanda tanda berbunga. Baik pedagang maupun petani melakukan penaksiran berdasarkan hasil-hasil cengkeh tahun lalu. Jika harga penawaran disetujui, maka terjadilah transaksi jual beli. Hasil cengkeh petani yang telah diijonkan tersebut menjadi milik pedagang pada saat panen cengkeh yang akan datang. Sistem ini dapat berkembang bukan semata-mata keinginan para pedagang saja tetapi merupakan kebutuhan bersama antara pedagang dan petani.

Pedagang memerlukan bisnis sedangkan petani memerlukan uang karena pada saat menjelang panen biasanya petani sudah kehabisan uang untuk memenuhi berbagai keperluan konsumsi sehari-hari. Keperluan akan uang untuk membayar utang untuk membiayai sekolah anak/kemenakan merupakan alasan kedua yang cukup penting. Dalam upaya menaikan martabat keluarga, petanipun ada yang menjual bunga cengkeh yang masih di pohon untuk mendapatkan uang guna memperbaiki rumah dan keperluankeperluan konsumtif lain yang sebenarnya dapat ditunda misalnya pesta perkawinan atau selamatan tertentu untuk sesuatu hajat. Dari segi obyektif dan penilaian ekonomis, sistem ijon merugikan petani, tetapi dasar pertimbangan petani pada saat itu bukanlah bersifat ekonomis, tetapi sosial.

Secara umum pemasaran cengkeh di Koto Anau pada tahun 1950-an telah melibatkan beberapa lembaga perantara, seperti rantai pemasaran adalah dari petani kepada pedagang dan selanjutnya kepada pedagang pengumpul yang ada di Padang. Selanjutnya rantai pemasaran juga melalui lembaga-lembaga perantara ini beroperasi 
pada tingkat pasar nagari, pasar transit di ibukota kecamatan/kabupaten dan pasar di Padang. Dalam pemasaran cengkeh, keuntungan yang cukup besar diperoleh oleh lembaga-lembaga perantara. Kurang lebih 50\% keuntungan diperoleh oleh lembaga-lembaga perantara tersebut. Salah satu usaha pemerintah menolong para petani cengkeh dari keadaan yang kurang menguntungkan itu ialah dengan membentuk koperasi yang akan berusaha mengurangi kerugian yang diderita oleh petani di bidang pemasaran.

Tahun 1962 dengan berbadan hukum No 29/BH/XVII/26 juli 1962 berdiri koperasi petani cengkeh di Koto Anau dengan nama Koperasi Petani Tjengkeh Koto Anau (KOPETEKA). Koperasi ini merupakan organisasi, karena tujuan utamanya adalah memajukan ekonomi petani dalam bidangproduksi dan pemasaran hasil. Koperasi menyalurkan cengkeh petani kepada Pusat Koperasi Pertanian Cengkeh Daerah TK I Sumatera Barat di Padang. Akan tetapi tidak semua petani menyalurkan cengkehnya melalui koperasi.

Berhubungan dengan itu tidaklah mengherankan kalau pedagang pengumpul tidak dianggap sebagai masalah yang serius. Alasan lain membuat petani tidak menjual cengkeh kepada koperasi karena mereka bukan anggota koperasi. Akhirnya terdapat juga petani yang tidak menjual cengkehnya kepada koperasi karena yang bersangkutan sudah terikat dengan pedagang. Pedagang telah memberikan petani pinjaman uang sebelum panen datang, walaupun tidak ada ikatan yang mengarah kepada sistem ijon. Data mengenai petani tidak menjual cengkehnya kepada koperasi tidak berhasil dikumpulkan, tetapi dari para petani yang diwawancarai mengatakan bahwa mereka pernah tidak menjual cengkehnya kepada koperasi.

Menurut mereka menjual cengkeh kepada koperasi memakan waktu yang lama karena harus diantarkan ke kantor kopersi. Sebaliknya transaksi dengan pedagang atau pedagang pengumpul lebih cepat sebab pedagang bersedia menjemput cengkeh yang dibeli kerumah atau ke ladang. Dalam keadaan seperti ini para pedagang mengumpul menempati fungsi ekonomi tertentu yang diperlukan dalam perekonomian pedesaan. Bagi petani pekerja pedagang pengumpul tersebut merupakan hal biasa dan petani menganggapnya sebagai suatu pekerjaan yang bermanfaat. Hal ini disebabkan pedagang pengumpul pada umumnya bukanlah "orang-orang asing" bagi petani. Banyak diantara mereka itu adalah sebagian dari warga desa, dan diantaranya ada yang termasuk keluarga sendiri.

Dengan demikian, petani hanya mempunyai 2 jalur pemasaran, yaitu pedagang pengumpul dan koperasi. Bagi para petani yang tidak ikut sebagai anggota koperaasi, maka banyak yang memilih pasar sebagai tempat pemasaran hasil cengkehnya. Bentuk pemasaran pada dekade 1960-an dapat digambarkan sebagai berikut ;

Gambar 1

\section{Jalur Pemasaran Cengkeh Dekade 1960}

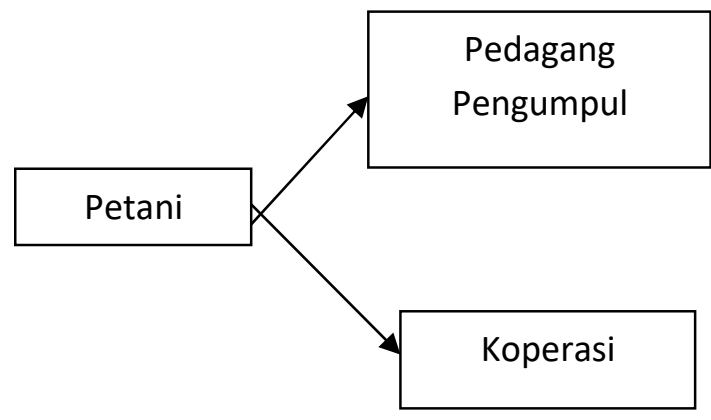

Pola pemasaran ke dua jalur sebagaimana diuaikan di atas hanya berlangsung sampai pada tahun 1975, karena setelah tahun ini cengkeh di Koto Anau mulai tidak menghasilkan. Para petani yang masih memiliki pohon cengkeh, menjual hasil cengkeh mereka kepada pedagang pengumpul yang ada di pasar saja, karena hasil cengkeh mereka hanya sedikit. Hal ini berlangsung sampai tahun 1990, petani menjual hasil cengkehnya langsung kepada pedagang pengumpul. Di samping itu para pedagang pengumpul banyak yang bersedia membeli cengkeh, karena bisnis menjadi pedagang pengumpul cengkeh masih menggiurkan.

Jalur pemasaran cengkeh pada dekade 1970-an sampai 1980-an mempunyai 3 bentuk jalur pemasaran, sebagaomana terdapat pada bagan di bawah ini; 
Gambar 2

Jalur Pemasaran Dekade 1970-an Sampai1980-an

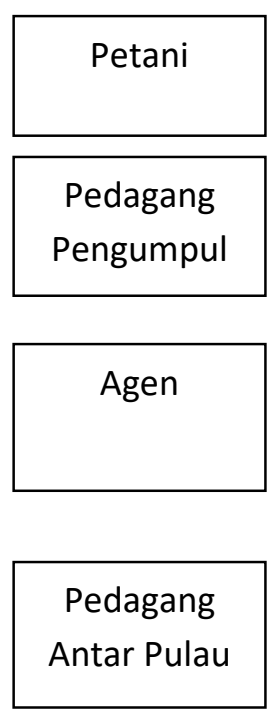

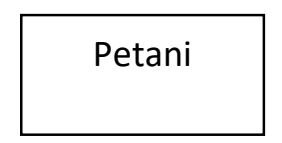
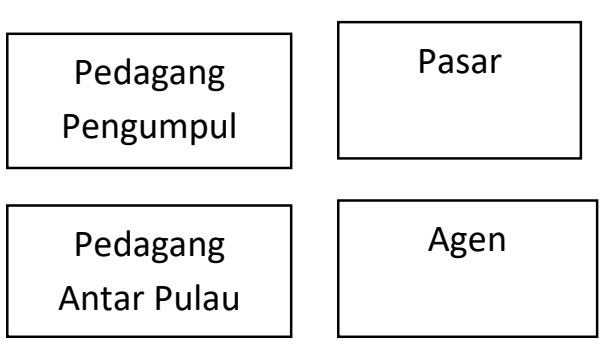

Pedagang

Antar Pulau

Pada jalur I dan II umumnya para pedagang pengumpul yang datang langsung ke kebun cengkeh untuk membeli cengkeh para petani. Dalam hal ini petani cukup menyiakan cengkeh yang siap untuk dijual. Sedangkan pada jalur III para petani harus mendatangkan pasar untuk menjajakan cengkehnya kepada agen yang ada namun disamping itu bagi petani yang mempunyai hasil cegnkeh yang banyak, mereka ada yang menjualnya langsung kepadapedagang ypengumpul pedagang yang berkumpul di padang. Menurut mereka dengan cara ini lebih menguntungkan jika cengkeh langsung dijual ke pasar, baik dari segi waktu, dana dan tenaga.

Selanjutnya jalur pemasaran pada tahun 1990 sampai tahun 2011 terrdapat pada gambar berikut;

\section{Gambar 3 \\ Jalur Pemasaran Cengkeh Tahun 1990- 2011}

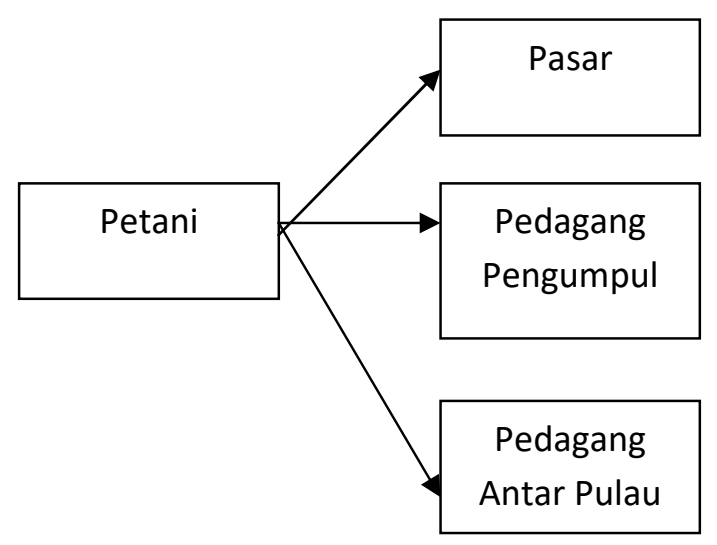

Pada tahun 1990 sampai 2011 para petani lebih banyak mempunyai jalur-jalur pemasaranya, tidak tertumpu kepada satu pihak. Para petani mempunyai kebebasan untuk menjual cengkehnya ke pasar, pedagang pengumpul atau pedagang antar pulau. Semua itu tergantung kepadaseberapa luas relasi para petani kepada pihak-pihak yang mampu membeli hasil cengkehnya.

\section{PASANG SURUT EKONOMI PERTANIAN CENGKEH DI KOTO ANAU}

Dalam rentangan sejarah, manusia selau berupaya untuk memenuhi kebutuhanya dengan berupaya mengolah alam sekitarnya. Pertumbuhan penduduk dan pembagian tanah yang terus dilakukan kepada anak cucu mengakibatkan terjadinya penyempitan lahan (Firdaus, 2012). Manusia selalu mencari keuntungan di berbagai kegiatan yang dilakukanya. Pada dasarnya ini dilakukan untuk melanjutkan kelangsungan hidupnya di dunia ini. Dalam beberapa dekade masyarakat Koto Anau selalu berupaya untuk mencari keuntungan dalam perjalanan sejarahnya. Namun bagi masyarakat Koto Anau hasil cengkeh mampu membuat dinamika tersendiri dalam kehidupan sosial ekonomi masyarakat Koto Anau. Masyarakat Koto Anau yang awalnya adalah petani penggarap sawah dan merupakan kegiatan utama mereka, namun dengan keuntungan yang didapatkan berubah kepada mengolah cengkeh sebagai kegiatan utamanya.

Hasil cengkeh di Koto Anau telah mampu membuat masyarakat Koto Anau dapat hidup sejahtera. Para petani dapat menikmati hasil cengkehdan merubah pola hidup mereka. Pada awalnya petani hanya mengandalkan hasil padi sawah, namun dengan mengelambungnya hasil cengkeh telah mampu menjadikan mereka sebagai petani yang sejahtera.

Namun kesejahteraan petani tidak bisa bertahan lama. Para petani mengalami masa-masa sulit, dimana banyak pohon cengkeh yang terserang penyakit yang menyebabkan cengkeh "mati bujang" atau "mati gadis". Dalam hal ini Para petani mengalami masa-masa sulit. Para petani berupaya mencari kegiatan yang lain yang mau mengembalikan kesejahteraan mereka. Banyak para petani yang merantau dengan 
usaha lain, namun juga ada petani yang masih bertahan mengolah cengkeh dengan harapan bisa mendapatkan keuntungan dengan hasil cengkeh.

Pada saat harga cengkeh turun secara drastis, Para petani mengalami masa-masa sulit. Para petani kembali melakukan kegiatan yang lain yang mampu untuk kelangsungan hidupnya dan agar para petanidapat hidup sejahtera. Ada beberapa para petani yang memilih merantau, terutama yang masih muda dan ada beberapa petani yang masih menetap di Koto Anau tetapi tidak mengolah cengkehnya. Pada saat harga cengkeh turun di pasaran, para petani semakin tidak memperdulikan cengkeh. Kondisi di atas berbeda pada saat harga cengkeh naik kembali. Dalam kondisi ini masyarkat Koto Anau kembali berbondong-bondong mengolah cengkeh,btermasuk masyarakat Koto Anau yangada di rantau ikut serta melirik cengkeh sebagai usahanya. Para perantau umumnya menanamkan modal untuk investasi jangka panjang.

Berdasarkan hal di atas dapat dipahami bahwa tanaman cengkeh telah mampu membuat dinamika dalam kehidupan sosial ekonomi masyarakat Koto Anau. Hal ini terbukti pada beberapa dekade telah terjadi pasang surut dalam kehidupan sosial ekonomi masyarakat Koto Anau. Pada era tahun 1950-an Koto Anau menjadikan bertani cengkeh sebagai kegiatan utamanya dan mereka mendapatkan hasil yang memuaskan dari cengkeh.menurut hasil wawancara penulisan dengan petani cengkeh bahwa pada tahun 1950-an harga cengkeh melonjak tinggi, $1 \mathrm{~kg}$ cengkeh sama dengan harga 1 emas. Hasil cengkeh pada tahun1950-an telah mampu merubah pola masyarakat Koto Anau sebagai masyarat yang sejatra pada waktu itu. Masyarakat Koto Anau umumnya mempunyai batang cengkeh dan telah menjadi dinamika dikalangan masyarakat Koto Anau bahwa sangat rugi apabila tdak mempunyai pohon cengkeh.kebeuntungan bagi petani cengkeh berlangsung sampai sampai awal tahun 1960-an

Pada awal tahun 1960 masyarakat Koto Anau masih merasakan hasil cengkeh. namun tahun 1992 merupkan masa-masa dimana petani cegnkeh mandpatkan ujian. Menurut Mansur salah satu bahwah pada tahun 1962 pada saat cengkeh-cegnkeh di Koto Anau diserang oleh penyakit dan petani tidak tahu cara mengatasi agar penyakit cengkeh tersebut semakin berbahaya. Akinat dari serangan penyakit tersebut banyak petani cengkeh mengalami kerugian besar. Penyakit yang tidak diduga oleh petani telah membuat petani panik. Karena tidak tahu cara mengobati penyakit tersebut.

Akibat dari serangan penyakit tersebut juga berpengaruh terhadap pendapatan para petani. Dengan adanya serangan penyakit tersebut maka secara drastis juga berpengaruh terhadap hasil panen cengkeh. banyak cengkeh yang mengalami gagal panen dan pendapatan para petani turun secara drastis. Pada tahun 1970-an penyakit cengkeh masih menyerang pohon cengkeh. pada tahun 1970-an merupakan masa-masa dimana cengkeh mati karena diserang berbagai penyakit. Banyak cengkeh mati sebelum berbuah. Efek kejadian ini banyak petani cengkeh semakin mendapatkan ujian. Sesuai dengan hasil wawancara penulis bahwa petani banyak memilih untuk merantau ke tempat yang lain dengan usaha yang baru. Banyak masyarakat Koto Anau yang memilih berdagang daging, sehingga banyak pemuda Koto Anau dikenal dengan sebutan tukang bantai. Namun masih ada beberapa petani yang masih bertahan mengolah cengkeh, namun jumlahnya tidak banyak. Efek dari para petani yang merantau juga berpengaruh terhadap populasi penduduk di Koto Anau , sebagaimana yang telah penulis tampilkan pada bab sebelumnya. Di samping itu, petani cengkeh yang hanya bertahan adalah petani yang berusia tua dan tidak produktif lagi.

Pada tahun 1980-an merupakan masamasa dimana masih ada beberapa petani yang memilih bertahan untuk mengolah cengkeh, walaupun pada saat ini harga cengkeh turun secara drastis. Para petani yang masih bertahan tersebut merupakan petani yang telah tua dan tidak sanggup untuk melakukan pekerjaan yang berat. Beberapa petani yang masih bertahanmengolah cengkeh yaitu Nursin, Tahar Malintang, Katik Sanggo, dan Mansur.

Dinamika yang terjadi pada tahun 1990-an adalah dimana masyarakat Koto Anau dan para perantau kembali melirik 
usaha mengolah cengkeh. Mereka kembali giat menanam cengkeh pada lahan cengkeh yang terbengkalai. Pada saat ini harga cengkeh kembali naik walaupun tidak sebanding dengan harga cengkeh sebelumnya. Menurut Tahar Malintang bahwa harga cengkeh pada tahun 1990-an berkisar Rp. 10.000 sampai dengan Rp. $15.000 / \mathrm{kg}$ harga ini lebih tinggi dibanding dengan harga cengkeh pada tahun 1980 yang hanya berkisar Rp.250 sampai Rp. 500 per kg.

Kenaikan harga cengkeh pada tahun 1990-an telah mampu merubah perhatian masarakat Koto Anau dan para perantau untuk kembali mengurus lahan yang terbengkalai, untuk ditanami cengkeh. bagi para perantau umumnya mereka menanam modal dan pengolahanya diberikan pada buruh petani. Pada tahun 2000 -an merupakan masa-masa dimana masyarakat Koto Anau telah kembali sejahtera dengan hasil cengkeh. masyarakat Koto Anau semuanya memiliki pohon cengkeh, namun yang membedakan adalah jumlahmya.ada petani yang mempunyai cengkeh dalam jumlah sedang dan juga yang mempunyai beberapa batang cengkeh. harga cengkeh semenjak tahun 2000 sapai 2011 berkisar Rp. 20.000 sampai Rp. 25.000 per kilogram untuk cengkeh basah. Sedangkan untuk cengkeh kering harganya berkisa Rp. 100.000 sampai Rp. 125.000 perkilogram.

Tabel 3.

\section{Daftar Harga Cengkeh}

\begin{tabular}{|l|l|l|}
\hline No & Tahun & $\begin{array}{l}\text { Harga cengkeh }(\mathrm{Rp}) \text { per } \\
\text { kg }\end{array}$ \\
\hline 1 & $1980-\mathrm{an}$ & $250-500$ \\
\hline 2. & $1990-\mathrm{an}$ & $10.000-15.000$ \\
\hline 3. & $2000-\mathrm{an}$ & $20.000-25.000$ \\
\hline
\end{tabular}

Beberapa dekade yang penulis tampilkan diatas terlihar beberapa perubahan yang dialami oleh masyarakat petani cengkeh di Koto Anau. Pasang surut sosial ekonomi telah dialami oleh masyarakat Koto Anau. Namun pada dasarnya bertani cengkeh telah mampu membuat kehidupan masyarakat Koto Anau menjadi pasang surut dan embuat dengan lengkap dalam kehidupanya. Hasil cengkeh telah mampu membuat masyarkat Koto Anau menjadi sejahtera, namun cengkeh juga bisa membuat masyarakat Koto Anau hidup kesulitan dan sempat mengabaikan cengkeh. namun pada saat ini masyarakat Koto Anau telah menjadikan cengkeh sebagai tanaman yang mampu meningkatkan penghasilan mereka.

\section{KESIMPULAN}

Pertanian cengkeh dalam beberapa dekade sejak diperkenalkan telah menjadi sumber ekonomi utama masyarakat nagari Koto Anau dan bahkan menjadi prestise bagi mereka. Bahkan, di masa-masa puncak dimana harga cengkeh sangat tinggi, cengkeh lebih berharga dari tanaman makanan pokok karena nilai ekonomi yang sangat tinggi. Namun, sebagai komoditi pertanian, cengkeh juga mengalami pasang surut karena faktor hama dan harga. Pada masa hama dan harga rendah, kondisi sosial ekonomi masyarakat mengalami guncangan dan bahkan nyaris ambruk sehingga menyebabkan sebagian petani frustasi dan menjadikan rantau sebagai pelarian. Namun demikian, tidak semua masyarakat memilih merantau, sebagian tetap bertahan dan merawat cengkeh meskipun diserang hama dan harga murah. Demikianlah cengkeh telah menjadikan segala sendi dan aspek sosial ekonomi masyarakat Koto Anau mengalami perubahan. Namun, kemampuan masyarakat dalam mengelola hasil pertanian mereka di musim harga mahal dan bagus tidak sebanding dengan goncangan ekonomi saat kesehatan dan harga cengkeh anjlok.

\section{DAFTAR PUSTAKA}

Alaudin, C. (1977). Cengkeh. Aceh: Universitas Syah Kuala.

Djafaruddin. (1970). Analisa Tidak Normalnya Pembuangan dan Kematian Cengkeh di Perkebunan Bukit Tambun Tulang. Padang: Lembaga Penelitian Universitas Andalas.

Firdaus, F. (2012). Puar Cama Untuk Anak Cucu: Kearifan Lokal Untuk Sustainability Forest di Manggarai Barat. Jurnal Ilmu Sosial Mamangan, 1(1), 39-50.

Irdawati. (1997). Tanaman Cengkeh Dalam Kehidupan Petani Koto Anau 19501970. Universitas Andalas, Padang.

Sartono, K. (1988). Pengantar Sejarah Indonesia Baru 1500-1900, Dari 
Imporium Sampai Imperium Jilid I.

Jakarta: PT. Gramedia.

Sudarmo, S. (2005). Pestisida Nabati:

Pembuatan dan pemanfaatanya.

Yogyakarta: Kanisius.
Zubir, Z. (1987). Peranan Madrasah Diniyah Koto Anau Dalam Pendidikan Islam di Kabupaten Solok. Universitas Andalas, Padang. 
